\title{
The socio-demographic profile of Spanish adult undergraduates: university-level compensatory policies vs life-course (dis)advantages
}

\author{
Alfredo Alfageme \\ Universitat Jaume I, Castellón, Spain and \\ Department of Philosophy and Sociology, Universitat Jaume I, Castellón, Spain \\ Salvador Seguí-Cosme \\ Department of Philosophy and Sociology, Universitat Jaume I, Castellón, Spain, and \\ Yazmín Monteagudo-Cáceres \\ Universitat Jaume I, Castellón, Spain
}

\begin{abstract}
Purpose - To uncover age inequalities in participation in higher education (HE) in Spain, the sociodemographic profile of Spanish adult undergraduates is compared to that of the general population of the same age group (25-54). Specific attention is devoted to differentials between face-to-face and distance adult students.

Design/methodology/approach - The study is mainly based on a comparative analysis of quantitative data generated by an online survey conducted by the authors among students over the age of 25 enrolled in Spanish public universities. Concurrent secondary sources have been considered as well.

Findings - Employment and family obligations appear as powerful conditioners of adults' access to HE, their choice of study mode (face-to-face or distance) and their area of study. The possession of previous HE qualifications also appears as an important factor differentiating adult undergraduates from the general population.

Research limitations/implications - The online survey is intended to reveal the main socio-demographic barriers to adult access to $\mathrm{HE}$ in Spain, rather than to draw a statistically representative profile of the target universe. The standard methodological recommendations have been followed to control the expected low response rate for the online questionnaire.

Practical implications - The study points to the need to deeply articulate current university-level compensatory mechanisms with macro-level age-sensitive social policies.

Social implications - Life course policies aimed at reducing age educational inequalities are advanced.
\end{abstract}

(C) Alfredo Alfageme, Salvador Seguí-Cosme and Yazmín Monteagudo-Cáceres. Published in Journal of Applied Research in Higher Education. Published by Emerald Publishing Limited. This article is published under the Creative Commons Attribution (CC BY 4.0) licence. Anyone may reproduce, distribute, translate and create derivative works of this article (for both commercial and non-commercial purposes), subject to full attribution to the original publication and authors. The full terms of this licence may be seen at http://creativecommons.org/licences/by/4.0/legalcode

This work was supported by the Universitat Jaume I under Grant ref. UJI-B2016-22. The authors are grateful for the collaboration of the Statistical Information Service of the General Secretariat of Universities of Spain, the Universitat Autónoma de Barcelona, the Universidad Complutense de Madrid, the Universidad Nacional de Educación a Distancia (Associated Centres in Calatayud, Elche and Vilareal), the Universitat Oberta de Catalunya, and the Universities of A Coruna, Barcelona, Granada, Illes Balears, Murcia, Oviedo, País Vasco, Salamanca and Zaragoza. 
Originality/value - The social conditioners of adult participation in $\mathrm{HE}$ are addressed through a conceptual framework combining the life-course perspective with the prevalent research approach, centred on the notions of lifelong learning and non-traditional learners' unequal access.

Keywords Adult education, Higher education, Distance education, Education policy, Life course, Social inequality, Spain

Paper type Research paper

\section{Introduction}

The main objective of the research presented here is to compare the socio-demographic profile of Spanish adult undergraduates with that of the general population of the same age group (25-54), distinguishing between face-to-face and distance students. The objective stems from a concern with equity in relation to the participation of adult students in higher education (HE): Assuming with Ariño that the reflection of the diversity of the population in the student body is a paramount indicator of equity, "[t]he question to be investigated [...] is to what extent the education system -in our case, the university system-reflects the existing inequalities in the social structure" (2014, p. 13 [our translation]).

As can be checked in the successive EUROSTUDENT rounds, including number VII (2018-2021), adult students have been representing high percentages of the student body in diverse countries of the European Higher Education Area (EHEA) for quite a long time but have nonetheless remained underrepresented in various spheres such as technical and scientific studies (together with women). Their underrepresentation is, unsurprisingly, especially high in face-to-face and full-time conventional studies, and Spain has not been an exception to such trends. Spanish adults, however, have also been disproportionately turning to the distance-learning mode ( $c f$. infra), if anything else, because the part-time study status, although legally foreseen, is in practice hardly applied. Altogether, research on nontraditional Spanish students, in general, and on adult students, in particular, has declined in recent years, after the momentum gained from the initial implementation of the EHEA waned. As for the face-to-face vs distance learning divide, it has not specifically been addressed in the Spanish case in relation to adult students.

This research has been limited to adults in the 25-54 age range. The 25-year edge is conventional in the literature on non-traditional $\mathrm{HE}$ students to distinguish youth from adults, whereas learners above 54 are prone to hold distinctive motivations often met by university programmes for older adults (Cabedo and Alfageme, 2006; Fernández et al., 2014). The study has been limited, as well, to university undergraduates, since HE is in Spain almost exclusively provided by universities (superior music conservatories are an exception) and undergraduate programmes tend to concentrate the whole range of $\mathrm{HE}$ objectives, as opposed to postgraduate programmes, more clearly oriented, in most cases, to the acquisition of specific labour qualifications.

The investigation has confirmed that in the times immediately preceding the COVID-19 pandemic, the difficulties to reconcile studies with work and family responsibilities remained the predominant barrier to adult participation in Spanish undergraduate courses. Another notable result, however, was far from obvious at the start: namely, the fact that adults with previous HE qualifications are very highly overrepresented in the target group (undergraduates) in comparison with the general population of the same age group (25-54), especially in the distance modes. More in line with expectations, the profile of face-toface undergraduates remained much more divergent from that of the general population than that of distance undergraduates.

Although there is increasing evidence that at-risk students, including many adult ones, "will disproportionately be affected by the COVID-19 pandemic", this might well be interpreted as an opportunity "to place the social dimension as a top priority in the post- 
COVID-19 recovery in higher education" (Hauschildt et al., 2021, pp. 10-11). The social dimension of the EHEA has indeed set the bulk of the recent European research agenda on non-traditional students, in general, and adults, in particular, in a more or less comfortable dialogue, in the latter case, with the previous and simultaneous works revolving around the notion of lifelong learning. This research is part of these developments but intends to connect them with the life-course perspective, often overlooked and yet insightful: In relation to the participation of non-traditional students in $\mathrm{HE}$, the life-course approach leads to deeply consider the articulation of university-level programmes with macro-level public policies.

\section{Lifelong learning, the social dimension of higher education and the life course}

It has been widely acknowledged that education systems should be flexible enough to facilitate access to $\mathrm{HE}$ for a diverse population. As for universities, their central role in lifelong education and training has been underscored by international organisations long-lastingly concerned with education policies, such as the Organisation for Economic Co-operation and Development (OECD) and the United Nations Educational, Scientific and Cultural Organisation (UNESCO) (Yang et al., 2015). While education undoubtedly conditions one's employment opportunities, in today's world, this relationship is being extended into advanced stages of the life course. Globalisation processes, closely linked to advances in information and communication technologies, have intensified the effects of education on people's capacity to handle labour market risks throughout the life course (Buchholz et al., 2008). The OECD $(2011,2017)$ has indeed highlighted the polarisation of the value of employment qualifications, which are largely conditioned by the level of formal education achieved in the early stages of life. The European Commission has also been long-lastingly concerned with the role of lifelong learning (Official Journal of the European Union, 2019) and has underscored, specifically in relation to adults' education, the lack of a coordinated European system (European Commission, 2019). And, in more general terms, Ogg has recently reviewed "the domains where lifelong learning will play a leading role in meeting the challenges of ageing societies" (Ogg, 2021, p. 3): the extension of working life, the improvement of digital skills and healthy and active ageing in later life.

But, although certainly relevant from the demographic, labour and economic perspectives, discourses pivoting around the notion of lifelong learning can hardly avoid the feeling of carrying an instrumentalist vision of education. The critique of instrumentalism was indeed at the centre of the anti-Bologna protests in the late 2000s, and perhaps not without foundation: In his study on access of non-traditional students to HE, centred on the Swedish case, Bron concluded that "the European policy of mass HE emphasising employability and lifelong learning" might have pushed the system towards instrumentalism, particularly on the part of non-traditional students (2014, p. 64). Altogether, the latest European research agenda on adult participation in $\mathrm{HE}$ has mainly been connected to the politics of the social dimension of the EHEA.

Although initially mentioned in the Bergen Ministerial Communiqué (CEMRHE (Conference of European Ministers Responsible for Higher Education), 2005, p. 4), the social dimension of the EHEA was more ambitiously addressed in the decisive London Communiqué: In it, the aim to remove the "obstacles related to [the students'] social and economic background" is approached in terms of equity, or, in its own words, of sharing "the societal aspiration that the student body entering, participating in and completing higher education at all levels should reflect the diversity of our populations" (CEMRHE, 2007, p. 5). The social dimension of the EHEA reverted from the political to the research agenda, mainly through the well-known European projects such as RANHLE (Access and Retention Experiences of Non-Traditional Learners in Higher Education), Acess4all and EUROSTUDENT, with national counterparts, such as, in the Spanish case, ECOVIPEU-11 
(Encuesta de Condiciones de Vida y Participación de los Estudiantes Univesitarios [Survey of Living Conditions and Participation of University Students]) (Ariño, 2014). The aims and the vocabulary of the projects have been progressing from access and participation to integration and, more recently, to inclusiveness (a prominent notion in the Rome Communiqué (CEMRHE, 2020, p. 5)), but a certain feeling of not reaching the proposed objectives can be detected in part, at least, of the associated literature. Thus, for example, Padilla-Carmona et al. have pointed out the insufficient attention to diversity in the Spanish case (2020), or, in more general terms, Pérez-Maldonado and Gairín have noted that the logic of excluded groups tends to view students as the problem rather than as individuals deserving of equal opportunity (2020, p. 135). In fact, the unequal participation of adult students in HE has frequently been approached from the ubiquitous notion of "non-traditional students" (those belonging to structurally underrepresented groups), without always delving into the operation of the underlying structural factors affecting individuals. Most of these factors, admittedly, are connected to previous life trajectories and easily transcend the standard inclusion capacities of $\mathrm{HE}$ centres.

In $\mathrm{HE}$ systems, meeting the requirements of lifelong learning and inclusiveness, the desire or responsible decision to attend university would ideally spring from a mature reflection that could take place at any stage of adult life, whether driven by vocation, by the need to adapt to a changing social and labour environment and/or by more intrinsic factors such as the pleasure of learning as an end in itself (Íñiguez and Marcaletti, 2017). This type of decision, however, remains unequally accessible within the EHEA, specifically in the case of adult students, as their persistent underrepresentation in relevant domains of $\mathrm{HE}$ demonstrates. Individuals and families most in need of an income from paid work are arguably those who in practice have the poorest opportunities to access formal learning, and this can in turn can be understood as part of the well-known tendency to accumulate advantage and disadvantage over the life course (Dannefer, 2020; Mortimer and Moen, 2016). In the area of education and training, this tendency has been documented in comparative studies of various OECD countries (Blossfeld et al., 2014; Lee and Desjardins, 2019) and in specific cases such as the United Kingdom (Bukodi, 2017) or Catalonia (Spain) (Miret and Vono, 2015).

The demand for equality policies ensuring greater access to education and training for adults in the underprivileged sectors of society (in terms of resources, accessibility and motivation) (Kilpi-Jakonen et al., 2015), insofar as it operates in a realm of cumulative disadvantage, seems to call for a life-course approach. On the academic side, the life-course perspective recognises the role institutions have played in separating life into stages (education, employment and retirement) that essentially revolve around (paid) work, and that the inherent inertia of these institutions has led to a structural lag which continues to the present day (Moen, 2016). Indeed, this separation process took place in very different historical circumstances. First, it is an androcentric conception grounded in a clear genderbased division of labour that relegated women to unpaid care work: It has indeed been documented that in all European countries, career-related motivations to get involved in educational activities are higher amongst men (Boeren and Holford, 2016). Second, this threestage life-course structure, ending with retirement, was configured for societies with much younger demographics, far removed from the present reality. Finally, in societies characterised by huge advances in information and communication technologies, there is a more obvious need for lifelong education, both to extend active working life (Phillipson, 2013) and for other reasons associated with personal development (Formosa, 2013).

Insofar as the life-course perspective involves considering social groups at a disadvantage from the point of view of the life stage in which their disadvantage arises (McDaniel and Bernard, 2012; Crosnoe and Benner, 2016), it appears as a valuable tool to inform macro-level devices aimed at fostering, beyond personal motivations and university-level mechanisms, adults' participation in formal $\mathrm{HE}$. The analysis of the social commitment to lifelong learning 
in Europe (Boyadjieva and Ilieva-Trichkova, 2018) and of the barriers to adult participation in educational activities (Roosmaa and Saar, 2016), while revealing notable differences among countries, confirms that structural and institutional factors must be considered together with individual characteristics. In this vein, Boeren (2017) advances the distinction between the micro-level (differences between adults), meso-level (education and training providers) and macro-level (country variation), all of which are interrelated while each one operates as a necessary but insufficient condition for adult participation in education. This approach decisively supersedes the social psychology tradition (centred on the micro) clearly reflected in Courtney's (1992) influential contribution. In Boeren's study, measures implemented by universities, such as age quotas or distance alternatives, are located at the meso-level, whereas more general public policies correspond to the macro-level. The convenience of articulating meso-level university programmes for adult access with macro-level social policies will be specified in the final conclusions and recommendations section, after the Spanish case has been presented and its results exposed and discussed.

\section{Adults' access to higher education in Spain in the European context}

As described above, research undertaken in Europe has examined the expansion of adult opportunities to access HE mainly within the more general framework of improving opportunities for non-traditional or disadvantaged learners (Orr et al., 2017; European Commission, 2018). Most countries offer access opportunities through second chance or bridging programmes and maintain an ample availability of distance and online $\mathrm{HE}$ programmes, as Spain does. In fact, as noted by González-Monteagudo and Padilla-Carmona, "the Spanish university has a certain tradition of openness to adult students in order to compensate for inequalities in access" (2017, p. 7 [our translation]). An age quota for adults aged over 40 with work experience has been in operation in the Spanish university system since 2008, together with a well-established distance and online offer. Additional age quotas have durably been functioning in Spain for adults over the ages of 25 (since 1971) and 45 (2008), who can gain access to superior education through specific exams (Boletín Oficial del Estado [Spanish Official State Gazette], 2014). Since 2013, the Ministry of Education has been publishing figures on how university students access HE, showing a distribution that has remained virtually constant over the years. Around $10 \%$ of those wishing to enrol in public universities take the entrance exam for adults over the age of 25 , whereas the access routes for over 40 and 45 years old account for 0.4 and $1.7 \%$, respectively (MECS, 2018). It should also be remarked that the success rates in the entrance exams for students over 25 and 45 years old are significantly lower than those corresponding to the general entrance exams.

Although adult access to $\mathrm{HE}$ exhibits considerable differences across Europe, some relevant general tendencies can be marked. It is in the early stages of life that HE is still predominantly undertaken the vast majority of students indeed gain admission through standard qualifications acquired at the end of their secondary schooling, whereas adult students remain principally attracted by distance universities, with much higher dropout rates than their face-to-face counterparts. Unsurprisingly, mature persons with family and employment responsibilities are the predominant profile in European distance institutions (Owusu-Boampong and Holmberg, 2015). As for the higher dropout rates in the distance mode, even considering that withdrawal does not always mean failure (Merrill, 2015), they seem to signal to the persistence of socio-economic barriers in adults' access.

The Spanish case is in line with such general European tendencies. First, access to HE mainly occurs immediately after secondary schooling, while distance universities persist as a minority resource: In the 2016-2017 academic year, only 12\% of Spanish university students were enrolled in the Universidad Nacional de Educación a Distancia (UNED, National Distance-Education University), the only nationwide public distance university (MECS, 2018) 
founded in the 1970s and well disseminated throughout the territory since the 1980s. Second, data are conclusive and revealing with regard to the students' age: In the 2016-2017 academic year, the proportion of Spanish undergraduates below the age of 25 laid at $77 \%$ in public universities as a whole, compared to only $17 \%$ in the UNED - a clear difference confirming the particular profile of distance students. Finally, as regard to dropout, for the 2009-2010 academic year intake of new students in Spanish public universities, the rate among distance students was $62.8 \%$, compared to $25.1 \%$ among face-to-face students (MECS, 2016). It certainly cannot be ignored that Spain stands among the European countries with the lowest rates of adults' access to HE (Souto-Otero and Withworth, 2017), while maintaining, as described above, similar enrolment devices available to adults, but such circumstance turns the Iberian country into a suitable case to raise awareness about the socio-demographic conditioners of adults' entrance into tertiary formal learning.

\section{Method}

The Spanish case has been tackled with a quantitative methodological approach. Primary data originate in an online survey conducted by the authors among university undergraduates in the 25-54 age group, whereas concomitant secondary data have been collected from the Centro de Investigaciones Sociológicas (CIS), the reference public centre for sociological research in Spain. Then, comparative analysis was used to identify differences between students and the general population of the same age group, and multivariate logistic regression to analyse the students' educational choices. It was decided to dispense with the family income variable, despite its undeniable relevance $a$ priori, since it usually obtains low response rates in different types of questionnaires, and low response rates are already to be expected in online questionnaires such as the one administered here. Also (and probably in relation to the above), this variable was not collected in the comparable CIS survey.

The online questionnaire was designed using a Google form and sent, in most cases by electronic mail, to a large sample of students in the target age group, requesting their voluntary participation. Spanish public universities were approached to collaborate in the administration of the survey. One section of the questionnaire relates to students' employment and family situations and borrows the same format as the Centre for Sociological Research recurring surveys so as to allow rigorous comparisons between the two sets of data (students and the general population). The second part of the survey includes questions on modes of access to university, type of studies and reasons to undertake studies.

To construct the sample, the largest universities were selected, for practical reasons and because they were assumed to be the most homogenous in terms of the range of courses being offered. Geographical diversity was also ensured. Finally, the participation of students from the only Spanish public distance university, the aforementioned UNED, was considered essential. The percentage of distance students (UNED) in the sample was $15 \%$, compared to $12 \%$ in the universe, according to the data from the Ministry of Education referred to above. A weighting factor was not introduced, considering that the differences between face-to-face and distance students were of more interest than the results referring to students as a whole. Furthermore, a heterogeneous sample of a significant size was sought rather than a statistically representative one. The final sample comprised 1,990 students enrolled in the following universities: Universidad Complutense de Madrid (817), the Universities of A Coruña (195), Granada (133), Illes Balears (124), Oviedo (223) and Zaragoza (197), and the UNED Associated Centres in Calatayud, Elche and Vila-real (301). The survey was conducted from March to July 2018. The composition of the sample by sex and age (which will also be discussed in the next section) is presented in Table 1. 
Despite the low response rates to be expected in online surveys, sometimes even below 10\% (Díaz de Rada, 2012; Van Mol, 2017), this option was deemed justified in this study, given the types of analysis that had been planned in accordance with the aforementioned sampling scheme. In any case, data were controlled ex post by comparing them with alternative sources, as recommended in the above-mentioned studies. The survey results proved to be very similar to those published by the Ministry of Education when data were comparable, as in the cases of age distribution, areas of study and university access modes. The percentage of women was nonetheless significantly greater in the survey, possibly due to their higher academic performance (see Europa Press, 2018), which in turn may be related to their higher participation in the university system.

\section{Results and discussion}

In line with the main objective of the investigation, data on the profile of university students compared to the profile of the general population are first presented. Next, the factors contributing to students' choice of the distance mode are analysed. As already described above, the overrepresentation of adults in the distance mode (and their corresponding underrepresentation in the face-to-face option) is very noticeable in the Spanish case. Also, the face-to-face vs distance divide has been considered symptomatic of the overall barriers that adult HE learners face in the Spanish university system and, consequently, as worthy of specific attention.

\section{Comparative social profile of university students and the general population}

Table 2 reports a series of indicators referring to undergraduate students aged between 25 and 54 and for the general population in the same age group (most of whom are not students). The use of percentage indicators permits an intuitive overview of the relevant and varied information grouped in the same table. The students' data are presented separately for the face-to-face and distance modes. In line with other European studies (Owusu-Boampong and Holmberg, 2015), the results show much greater similarities between the distance student profile and the general population profile than the traditional face-to-face student profile, with a lower proportion of women and higher percentage of relatively more mature people who live with a spouse/partner, have children and work full time.

A marked difference in age between on-campus and distance students can be noted, probably related to the fact that many youngsters simply continue studying after finishing high school or other previous studies. However, face-to-face students over the age of 25 are also highly likely to be working, particularly in part-time or irregular jobs that give them the time to attend classes. Indeed, full-time employment is mainly associated with students studying at a distance, a result that coincides with findings from research carried out by the UNED (2017), yielding significantly higher percentages than for the general population. The fact of working (full time or part time) therefore seems to have an ambivalent effect on the likelihood of studying at university. On the one hand, it makes it difficult for obvious practical

\begin{tabular}{lccc}
\hline & & Age & \\
& $25-34$ & $35-44$ & $45-54$ \\
\hline Women & 64.8 & 56.7 & 61.9 \\
Men & 35.2 & 43.3 & 38.1 \\
& $(1,291)$ & $(420)$ & $(273)$
\end{tabular}

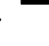


reasons; yet, on the other, it seems that being in paid employment in some way stimulates individuals to study. This impetus may be related to the desire for promotion at work or a change of career or might be attributable to individual characteristics at the micro level (dynamic personality, sociability or others).

Another noteworthy factor shown in Table 2 is family responsibilities. Specifically, living with a child or children introduces significant differences among the three categories analysed, which are clearly greater than those related to living with a partner. Looking after children obviously limits the possibilities available to parents for training or education, especially if, as is often the case, they are also in paid employment. This result is in line with the corresponding ones referring to Spain in EUROSTUDENT III and IV (Soler Julve, 2011, p. 58), the last rounds in which the country participated, and with those from the more recent study undertaken in Catalonia by Miret and Vono (2015), showing that sex does not influence the likelihood of adults entering formal education, but that having children does significantly reduce this probability. These results should nonetheless be cautiously analysed and considered in the light of a gender perspective. In fact, in the sample composition by sex and age, shown above in Table 1, the following can be observed: Within the 35 to 44 age group, when childcare is more likely, the sex composition of university adult students differs markedly from that of the other two groups (25-34 and 45-54): whereas the percentage of women remains higher in all three brackets, the difference with men shrinks notably in this particular one. This is in agreement with the EUROSTUDENT IV results indicating that men are more likely to reengage in HE later in life (Soler Julve, 2011, p. 54). Calasanti and Slevin (2001) had indeed argued that the combination of social inequalities grounded on age, sex and other factors are manifest in more or less complex processes that require further analysis, while Riach et al. (2015), in the same vein, have more recently proposed approaching gender and age within work and organisational studies as a phenomenon clearly greater than the sum of its parts.

Also of note is the relatively high presence among university students of individuals with previous $\mathrm{HE}$ qualifications. The differences are significant with respect to the general population both for face-to-face students and, to a greater extent, distance students. As in other studies cited above, our results therefore reflect a certain tendency to accumulate advantages through university education throughout the life course (Blossfeld et al., 2014;

Table 2.

Face-to-face and distance undergraduate students aged between 25 and 54 enrolled in Spanish public universities, and general population of the same age group, according to sex, age, family situation, employment situation and educational level Percentage indicators*

\begin{tabular}{lccc}
\hline & \multicolumn{2}{c}{ Students $^{1}$} & \\
& Face-to-face & Distance & General population \\
\hline Women & $64.4_{\mathrm{a}}$ & $52.8_{\mathrm{b}}$ & $50.2_{\mathrm{b}}$ \\
Over the age of 35 & $28.7_{\mathrm{a}}$ & $70.8_{\mathrm{b}}$ & $73.1_{\mathrm{b}}$ \\
Over the age of 45 & $10.4_{\mathrm{a}}$ & $32.9_{\mathrm{b}}$ & $37.7_{\mathrm{b}}$ \\
Live with spouse/partner & $39.7_{\mathrm{a}}$ & $67.7_{\mathrm{b}}$ & $70.8_{\mathrm{b}}$ \\
Live with child/children & $13 . \mathrm{a}_{\mathrm{a}}$ & $40.4_{\mathrm{b}}$ & $57.8_{\mathrm{c}}$ \\
In full-time work & $27 . \mathrm{a}_{\mathrm{a}}$ & $71.0_{\mathrm{b}}$ & $53.4_{\mathrm{c}}$ \\
In part-time work & $33.8_{\mathrm{a}}$ & $13.0_{\mathrm{b}}$ & $13.6_{\mathrm{b}}$ \\
Have higher education qualifications & $39.8_{\mathrm{a}}$ & $52.5_{\mathrm{b}}$ & $28.1_{\mathrm{c}}$ \\
& $(1,689)$ & $(301)$ & $(1,270)$
\end{tabular}

Note(s): *Values in the same row that do not share the same sub-index are significantly different $(z$ test, $p<0.05)$

Source(s): ${ }^{1}$ Authors' own survey of university students, 2018

${ }^{2}$ Centre for Sociological Research, study 3,207 (barometer March 2018). As this study does not include employment type, we considered that $80 \%$ of working people over the age of 25 is in full-time jobs (a highly stable percentage in previous studies) 
Lee and Desjardins, 2019). On the one hand, it can be argued that individuals who have already studied may be more likely to want to repeat the experience. This also occurs in the case of university programs for older adults (Cabedo and Alfageme, 2006). On the other hand, it is also likely that people with a university qualification will be in a relatively favourable socioeconomic position, which will in turn enhance their opportunities to continue studying throughout their lives. Other studies, in fact, have evidenced the importance of family income in this sense (Ariño, 2014) although this seems more recognisable in the case of younger university students (Engler, 2019).

\section{Factors influencing the choice of the "distance" mode}

The influence of various factors on the choice of the distance mode can more rigorously be evaluated by means of binary logistic regression analysis (Table 3). Whereas the type of university (face-to-face or distance) operates as the dichotomous dependent variable, independent variables were derived from the questionnaire in accordance with the interests of the study and the previous analytical framework. The table only reports data for the variables that show a significant influence. Dichotomous categorisations were used in all cases and the most relevant were selected to facilitate the interpretation of the results. The model's goodness-of-fit indices and its capacity to predict $85.6 \%$ of the cases were considered satisfactory.

By far the most influential factor is having a full-time job, which increases fourfold the likelihood of selecting the distance mode. Again, and clearly in tune with the premises of the Access4all project (2018), the need to work occupies a central place in adult decision-making. Advanced age, having children at home and a mainly non-instrumental motivation (not to enhance employment prospects or increase income) also have an impact but to a much lesser extent. As for the area of study, the factor that most determines the choice of the distance mode is opting for subjects other than architecture and engineering. Working full time clearly prevents or complicates face-to-face study, especially when combined with other factors such as having children. But the results also suggest the possibility that middle-aged adults with other alternatives might as well choose the distance mode not for instrumental reasons, but rather because they want to study as a way to enrich their lives or complement their interests or tastes at a relatively advanced age particularly in the area of arts and humanities. The distance mode of $\mathrm{HE}$ can in this sense be regarded as a healthy policy to facilitate lifelong learning, insofar as its limitations are not forgotten. As mentioned in the Introduction, it is the choice of a minority and distance universities have by far the highest dropout rates, admittedly, to a large extent, as a consequence of the dominant profile of their students, rather than because of the peculiarities of their learning mode. It is in fact known that, in general, dropout is significantly higher amongst older students (Bron, 2014; González-Monteagudo and Padilla-Carmona, 2017).

\begin{tabular}{|c|c|c|c|c|}
\hline & $B$ & Sig. & $\operatorname{Exp}(B)$ & \\
\hline $\begin{array}{l}\text { Sex (female/male) } \\
\text { Age (younger/older than 40) } \\
\text { Family responsibilities (lives/does not live with child/children) } \\
\text { Employment situation (in full-time employment/other situation) } \\
\text { Main motivation (non-instrumental/instrumental) } \\
\text { Area of study (arts and humanities/others) } \\
\text { Area of study (architecture and engineering/others) } \\
\text { Note(s): } n=1,968 ; \text { Nagelkerke } R^{2}=0.264 ; \text { predicted cases }=85.9 \% \\
\text { Source(s): Authors' own survey of university students, } 2018\end{array}$ & $\begin{array}{r}-0.359 \\
-0.662 \\
0.692 \\
1.525 \\
0.486 \\
0.439 \\
-0.854\end{array}$ & $\begin{array}{l}0.013 \\
0.000 \\
0.000 \\
0.000 \\
0.001 \\
0.012 \\
0.002\end{array}$ & $\begin{array}{l}0.698 \\
0.516 \\
1.998 \\
4.596 \\
1.626 \\
1.551 \\
0.426\end{array}$ & $\begin{array}{r}\text { Table } 3 . \\
\text { Factors that influence } \\
\text { choice of distance mode } \\
\text { among undergraduate } \\
\text { students aged between } \\
25 \text { and } 54 \text { enrolled in } \\
\text { Spanish public } \\
\text { universities. Results of } \\
\text { binary logistic } \\
\text { regression analysis }\end{array}$ \\
\hline
\end{tabular}

Spanish adult undergraduates

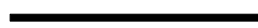




\section{Conclusions and recommendations}

In line with expectations, the results of the research presented here indicate that the situations typically associated with different stages of the life course, such as paid work or living with children, significantly reduce the probability that individuals will study at university. As for the face-to-face vs distance divide, the results reveal that the distance mode, with its huge dropout rates, absorbs up to four times more full-time workers than the traditional face-toface studies. The results also indicate the overrepresentation of persons with previous $\mathrm{HE}$ qualifications amongst Spanish adult undergraduates, compared to the general population of the same age group (25-54). This result suggests that in relation to adult participation, the Spanish university system tends to reproduce socio-educational inequalities, rather than functioning as a second-opportunity provider. Altogether, the findings suggest that current mechanisms to encourage adults' enrolment in undergraduate studies are not proving sufficiently effective as age-disadvantage compensators in the Spanish case. Insofar as the barriers to adult access that have been identified arise from cumulative (dis)advantage and the life course, the existing university-level instruments, such as age quotas, bridging programmes and distance alternatives, seem to claim a better coupling with macro-level social policies.

More far-reaching policies focussing on the life course would promote a more balanced distribution of the time citizens devote to different tasks or work during their lives. Thus, for example, current social-policy schemes in the realms of unemployment or minimum income, which do sometimes incorporate incentives linked to training trajectories, might benefit from more concrete couplings with given university programmes, such as, in the Spanish case, the UNED courses preparing for the university access examinations specifically designed for adults over the ages of 25 and 45 . In the case of working adults, university-level programmes might rather be coupled with study leave schemes.

Although study or training leave policies differ across European countries, they generally require permission from employers, cover short periods of time and are either badly paid or not remunerated at all. For reasons of general performance and equal access, it would be advisable that they be remunerated (Cedefop, 2012). In this vein, the European Foundation for the Improvement of Living and Working Conditions (Eurofound) has recognised the growing need to establish periods of work and non-work throughout the life course, whether for family reasons, for education or preparing for second or third careers, or other reasons (Eurofound, 2012, 2016). And, according to recent research in Spain, more than half the working population would consider the possibility of delaying their retirement in exchange for some years of paid temporary leave in order to study or train for a different career (Alfageme et al., 2019).

Further research on adults' unequal access to HE might thus benefit from a greater emphasis on social policies and, more specifically, on the articulation of university meso-level instruments with macro-level policies, taking into consideration cross-country differentials concerning both the socio-demographic profile of the adult student body and the existing policy mix.

\section{References}

Access4all Project (2018), "Developing a common wisdom of inclusion", available at: https:// access4allproject.eu/reports/view/developing-a-common-vision-of-inclusion (accessed 10 August 2021).

Alfageme, A., García-Pastor, B. and Seguí-Cosme, S. (2019), "Workers' willingness to delay retirement in exchange for temporary paid leaves: a case study in a Spanish town", International Journal of Sociology and Social Policy, Vol. 39 Nos 7/8, pp. 595-608, doi: 10.1108/IJSSP-03-2019-0053 (accessed 1 March 2021). 
Ariño, A. (2014), "Expansión de la educación y desigualdad”, in Ariño, A., Llopis, R. and Soler, I. (Eds), Desigualdad y universidad. La Encuesta de Condiciones de Vida y de Participación de los Estudiantes Universitarios en España, Universidad de Valencia, Valencia, available at: https:// roderic.uv.es/handle/10550/42244 (accessed 10 August 2021).

Blossfeld, H.P., Kilpi-Jakonen, E., Vono, D. and Buchholz, S. (Eds) (2014), Adult Learning in Modern Societies: An International Comparison from a Life-Course Perspective, Edward Elgar Publications, Cheltenham.

Boeren, E. (2017), "Understanding adult lifelong learning participation as a layered problem”, Studies in Continuing Education, Vol. 39 No. 2, pp. 161-175, doi: 10.1080/0158037X.2017.1310096 (accessed 1 March 2021).

Boeren, E. and Holford, J. (2016), "Vocationalism varies (a lot): a 12-country multivariate analysis of participation in formal adult learning”, Adult Education Quarterly, Vol. 66 No. 2, pp. 120-142, doi: 10.1177/0741713615624207 (accessed 1 March 2021).

Boletín Oficial del Estado (2014), "Real Decreto 412/2014 por el que se establece la normativa básica de los procedimientos de admisión a las enseñanzas universitarias oficiales de grado", available at: https:/www.boe.es/diario_boe/txt.php?id=BOE-A-2014-6008 (accessed 1 March 2021).

Boyadjieva, P. and Ilieva-Trichkova, P. (2018), "Adult education as a common good: conceptualization and measurement”, International Journal of Lifelong Education, Vol. 37 No. 3, pp. 345-358, doi: 10.1080/02601370.2018.1478458 (accessed 1 March 2021).

Bron, A. (2014), "Increasing access of non-traditional students to higher education", REPORTZeitschrift für Weiterbildungsforschung, Vol. 4, pp. 54-66, doi: 10.3278/REP1404W054 (accessed 10 August 2021).

Buchholz, S., Hofäcker, D., Mills, M., Blossfeld, H.P., Kurz, K. and Hofmeister, H. (2008), "Life courses in the globalization process: the development of social inequalities in modern societies", European Sociological Review, Vol. 25 No. 1, pp. 53-71, doi: 10.1093/esr/jcn033 (accessed 1 March 2021).

Bukodi, E. (2017), "Cumulative inequalities over the life course: life-long learning and social mobility in Britain”, Journal of Social Policy, Vol. 46 No. 2, pp. 367-404, doi: 10.1017/S0047279416000635 (accessed 1 March 2021).

Cabedo, S. and Alfageme, A. (2006), Los programas universitarios para mayores en España. Una investigación sociológica, Publicaciones de la Universitat Jaume I, Castelló.

Calasanti, T.M. and Slevin, K.F. (2001), Gender, Social Inequalities and Aging, AltaMira Press, CA.

Cedefop (European Centre for the Development of Vocational Training) (2012), Training Leave Policies and Practice in Europe, Publications Office of the European Union, Luxembourg, available at: https://www.cedefop.europa.eu/files/5528_en.pdf (accessed 1 march 2021).

CEMRHE (2005), "The European higher education area - achieving the goals", available at: https:// ehea.info/Upload/document/ministerial_declarations/2005_Bergen_Communique_english_ 580520.pdf (accessed 30 August 2021).

CEMRHE (2007), "London Communiqué. Towards the European higher education area: responding to challenges in a globalised world", available at: https://ehea.info/Upload/document/ministerial_ declarations/2007_London_Communique_English_588697.pdf (accessed 30 August 2021).

CEMRHE (2020), "Rome ministerial Communiqué", available at: https://ehea.info/Upload/document/ ministerial_declarations/2005_Bergen_Communique_english_580520.pdf (accessed 30 August 2021).

Courtney, S. (1992), Why Do Adults Learn? towards a Theory of Participation in Adult Education, Routledge, London.

Crosnoe, R. and Benner, A.D. (2016), "Educational pathways", in Shanahan, M.J., Mortimer, J.T. and Johnson, M.K. (Eds), Handbook of the Life Course, Springer, Cham, pp. 179-200.

Dannefer, D. (2020), "Systemic and reflexive: foundations of cumulative dis/advantage and life-course processes", Journal of Gerontology: Series B, Vol. 75 No. 6, pp. 1249-1263, doi: 10.1093/geronb/ gby118 (accessed 1 March 2021). 
Díaz de Rada, V. (2012), "Ventajas e inconvenientes de la encuesta por Internet”, Papers, Vol. 97 No. 1, pp. 193-223, doi: 10.5565/rev/papers/v97n1.71 (accessed 1 March 2021).

Engler, A. (2019), "Non-traditional students in higher education", Hungarian Education Research Journal, Vol. 9 No. 3, pp. 560-564, doi: 10.1556/063.9.2019.3.45 (accessed 10 August 2021).

Eurofound (2012), Working Time and Work-Life Balance in a Life Course Perspective, Eurofound, Dublin, available at: https:/www.eurofound.europa.eu/sites/default/files/ef_publication/field_ ef_document/ef1273en.pdf (accessed 1 march 2021).

Eurofound (2016), Sustainable Work throughout the Life Course: National Policies and Strategies, Publications Office of the European Union, Luxembourg, available at: https://www.eurofound. europa.eu/sites/default/files/ef_publication/field_ef_document/ef1610en_4.pdf (accessed 1 March 2021).

Europa Press (2018), Las universitarias tienen mejor rendimiento académico que sus compañeros, pero su inserción laboral y salario son peores, Europa Press, Madrid.

European Commission (2018), The European Higher Education Area in 2018, Bologna Process Implementation Report, Publication Office of the European Union, Luxembourg, available at: https:/eacea.ec.europa.eu/national-policies/eurydice/content/european-higher-education-area2018-bologna-process-implementation-report_en (accessed 1 march 2021).

European Commission (2019), Council Recommendation on Upskilling Pathways: New Opportunities for Adults Taking Stock of Implementation Measures (Commission Staff Working Document), SWD, Brussels, available at: https://ec.europa.eu/info/sites/info/files/file_import/implementationreport-upskilling-pathways_en.pdf (accessed 1 March 2021).

Fernández-García, A., García, J.L. and Pérez, G. (2014), "Los programas universitarios para mayores y su contribución al aprendizaje a lo largo de la vida", Revista Complutense de Educación, Vol. 25 No. 2, pp. 521-540, doi: 10.5209/rev_RCED.2014.v25.n2.42058 (accessed 1 march 2021).

Formosa, M. (2013), "Policies for older adults learning: the case of the European Union", in Field, J., Burke, R.J. and Cooper, C.L. (Eds), Aging, Work and Society, Sage, London, pp. 461-476.

González-Monteagudo, J. and Padilla-Carmona, M.T. (2017), "Políticas educativas en España y en Europa para estudiantes universitarios vulnerables y no tradicionales", in Guerrero Walker, G.J., Alcocer Vázquez, E. and Lafont, P. (Eds), Políticas públicas, sistemas y administración en educación y formación: ejemplos de países europeos, caribeños y latinoamericanos, Universidad Autónoma de Yucatán/Redford International, Yucatán, pp. 211-233, available at: https://idus.us. es/handle/11441/70525 (accessed 10 August 2021).

Hauschildt, K., Gwosć, C., Schirmer, H. and Wartenbergh-Cras, F. (2021), Social and Economic Conditions of Student Life in Europe EUROSTUDENT VII Synopsis of Indicators 2018-2021, wbv Media GmbH. KG, Bielefeld, available at: https://www.eurostudent.eu/publications\#result_ anker (accessed 30 August 2021).

Íñiguez, T. and Marcaletti, F. (2017), "Superando los mitos del envejecimiento en la inclusión educativa. Efectos de las variables sociodemográficas en las motivaciones de los adultos mayores para aprender", Revista de Educación Inclusiva, Vol. 10 No. 1, pp. 59-76.

Kilpi-Jakonen, E., Vono, D. and Blossfeld, H.P. (2015), “Adult learning and social inequalities: processes of equalisation or cumulative disadvantage?", International Review of Education, Vol. 61 No. 1, pp. 529-546, doi: 10.1007/s11159-015-9498-5 (accessed 1 March 2021).

Lee, J. and Desjardins, R. (2019), "Inequality in adult learning and education participation: the effects of social origins and social inequality", International Journal of Lifelong Education, Vol. 38 No. 3, pp. 339-359, doi: 10.1080/02601370.2019.1618402 (accessed 1 March 2021).

McDaniel, S. and Bernard, P. (2012), "Life course as a policy lens: challenges and opportunities", Canadian Public Policy - Analyse de Politiques, Vol. XXXVII, pp. S1-S13, doi: 10.3138/cpp.37. suppl.s1 (accessed 1 March 2021). 
MECS (2016), Datos y cifras del Sistema Universitario Español, Ministry of Education, Culture and Sport, Madrid, available at: https:/www.ciencia.gob.es/portal/site/MICINN/menuitem. 26172fcf4eb029fa6ec7da6901432ea0/?vgnextoid=364e006e96052710VgnVCM1000001d04140 aRCRD (accessed 1 March 2021).

MECS (2018), Estadística de estudiantes universitarios. Curso 2016-17, Ministry of Education, Culture and Sport, Madrid, available at: https://www.mecd.gob.es/servicios-al-ciudadano-mecd/ estadisticas/educacion.html (accessed 1 march 2021).

Merrill, B. (2015), "Determined to stay or determined to leave? A tale of learner identities, biographies and adult students in higher education", Studies in Higher Education, Vol. 40 No. 10, pp. 1859-1871, doi: 10.1080/03075079.2014.914918 (accessed 1 March 2021).

Miret, P. and Vono, D. (2015), Impacte de la formació d'adults en les trajectòries laborals, Fundació Jaume Bofill, Barcelona, available at: http://butlleticed.uab.es/butCED/num98_fitxers/Informe_ Resultats_Resum_Executiu.pdf (accessed 1 March 2021).

Moen, P. (2016), "Work over the gendered life course", in Shanahan, M.J., Mortimer, J.T. and Johnson, M.K. (Eds), Handbook of the Life Course, Springer, Cham, pp. 249-275.

Mortimer, J.T. and Moen, P. (2016), "The changing social construction of age and the life course: precarious identity and enactment of 'early' and 'encore' stages of adulthood", in Shanahan, M.J., Mortimer, J.T. and Johnson, M.K. (Eds), Handbook of the Life Course, Springer, Cham, pp. 111-129.

OECD (2011), Divided We Stand. Why Inequality Keeps Rising, Secretariado General de la OCDE, Paris, available at: https://www.oecd.org/els/soc/dividedwestandwhyinequalitykeepsrising.htm (accessed 1 March 2021).

OECD (2017), "Education at a glance 2017: OECD indicators", available at: https:/www.oecd-ilibrary. org/education/education-at-a-glance-2017_eag-2017-en (accessed 1 march 2021).

Official Journal of the European Union (2019), "Council conclusions on the implementation of the council recommendation on upskilling pathways: new opportunities for adults", Official Journal of the European Union, C189 (05/06/2019), available at: https://eur-lex.europa.eu/legal-content/ EN/TXT/PDF/?uri=CELEX:52019XG0605(01)\&from=RO (accessed 1 March 2021).

Ogg, J. (2021), Lifelong Learning in Ageing Societies: Lessons from Europe, UNESCO, Institute for Lifelong Learning, Paris, available at: https://uil.unesco.org/lifelong-learning/lifelong-learningageing-societies-lessons-europe (accessed 10 August 2021).

Orr, D., Usher, A., Haj, C., Atherton, G. and Geanta, I. (2017), Study on the Impact of Admission Systems on Higher Education Outcomes, Publications Office of the European Union, Luxembourg, available at: https://op.europa.eu/en/publication-detail//publication/9cfdd9c1-98f9-11e7-b92d01aa75ed71a1 (accessed 1 March 2021).

Owusu-Boampong, A. and Holmberg, C. (2015), Distance Education in European Higher Education the Potential, International Council for Open and Distance Education, Oslo, available at: https:// static1.squarespace.com/static/5b99664675f9eea7a3ecee82/t/5c86557008522903c3b034c2/ 1552307582370/ideal_report_3_extended.pdf (accessed 1 March 2021).

Padilla-Carmona, M.T., Martínez-García, I. and Herrera-Pastor, D. (2020), "Just facilitating access or dealing with diversity? Non-traditional students' demands at a Spanish university", European Journal for Research on the Education and Learning of Adults, Vol. 11 No. 2, pp. 219-233, available at: http://www.rela.ep.liu.se/article.asp?DOI=10.3384/rela.2000-7426.ojs850 (accessed 10 August 2021).

Pérez-Maldonado, C. and Gairín, J. (2020), "Barreras y facilitadores de acceso a la universidad percibidos por estudiantes que ingresan mediante vías no tradicionales/Barriers and facilitators perceived by students who access university through nontraditional pathways", Revista Espacios, Vol. 41 No. 26, pp. 132-146, available at: http://revistaespacios.com/a20v41n26/ 20412612.html (accessed 10 August 2021).

Phillipson, C. (2013), "Reconstructing work and retirement: labour market trends and policy issues", in Field, J., Burke, R.J. and Cooper, C.L. (Eds), Aging, Work and Society, Sage, London, pp. 445-460. 
Riach, K., Loretto, W. and Krekula, C. (2015), "Gendered ageing in the new economy: introduction to special issue", Gender, Work and Organization, Vol. 22 No. 5, pp. 437-444, doi: 10.1111/gwao. 12108 (accessed 1 March 2021).

Roosmaa, E.L. and Saar, E. (2016), "Adults who do not want to participate in learning: a cross-national European analysis of their perceived barriers", International Journal of Lifelong Education, Vol. 36 No. 3, pp. 254-277, doi: 10.1080/02601370.2016.1246485 (accessed 1 March 2021).

Soler Julve, I. (2011), "Características sociodemográficas", in Ariño, A. and Llopis, R. (Dirs), Universidad sin clases? Condiciones de vida de los estudiantes universitarios en España (Eurostudent IV), Ministerio de Educación, Secretaría General de Universidades, Madrid, available at: https://sede.educacion.gob.es/publiventa/universidad-sin-clases-condiciones-devida-de-los-estudiantes-universitarios-en-espana-eurostudent-iv/universidad-espana/14909 (accessed 30 August 2021).

Souto-Otero, M. and Whitworth, A. (2017), "Adult participation in higher education and the 'knowledge economy': a cross-national analysis of patterns of delayed participation in higher education across 15 European countries", British Journal of Sociology of Education, Vol. 38 No. 6, pp. 763-781, doi: 10.1080/01425692.2016.1158639 (accessed 1 March 2021).

UNED (2017), Situación laboral de los estudiantes matriculados 2017, UNED-COIE, Madrid, available at: http://coie.uned.es/observatorio (accessed 1 March 2021).

Van Mol, C. (2017), "Improving web survey efficiency: the impact of an extra reminder and reminder content on web survey response", International Journal of Social Research Methodology, Vol. 20 No. 4, pp. 317-327, doi: 10.1080/13645579.2016.1185255 (accessed 1 March 2021).

Yang, J., Schneller, C. and Roche, S. (Eds) (2015), The Role of Higher Education in Promoting Lifelong Learning, UNESCO Institute for Lifelong Learning, Hamburg, available at: https://uil.unesco. org/lifelong-learning/policies-database/role-higher-education-promoting-lifelong-learning (accessed 1 March 2021).

\section{Corresponding author}

Alfredo Alfageme can be contacted at: alfageme@uji.es

For instructions on how to order reprints of this article, please visit our website:

www.emeraldgrouppublishing.com/licensing/reprints.htm

Or contact us for further details: permissions@emeraldinsight.com 